\title{
アルミニウムと有機ハロゲン化物との 反応の誘導期についで
}

安川 $川 \quad$ 郎 $^{*}$

\section{On Induction Period of Reaction between Aluminum and Various Organic Halides Behavior of Aluminum on Various Organic Halides (Report 1)}

Saburo YASUKAWA*

Aluminum metal reacts with various organic halides to give aluminum halides at a very slow rate initially. Then the aluminum halide in this reaction system autocatalytically accelerates the reaction itself. So that, it needs an induction period to give the aluminum halide actually. When aluminum or aluminum alloy was washed by various chlorinated hydrocarbon to remove the oily dirt from its surface, much trouble caused from corrosive degradation of aluminum surface or explosive reaction owing to the autocatalytic reaction has been reported.

The present study has been made to prevent this trouble and also to clarify the mechanism of the reaction.

First, several methods of measuring the induction period were examined, from which a new simplified method to measure it rapidly and accurately was proposed.

Then, many experiments were carried out to ascertain the factor which controls the induction period.

As a result, it was suggested that the rate of the halogen radical formation from organic halide by heating was one of the most important factors which had much to do with the induction period.

\section{1. 緒言}

最近実用金属材料として発展をとげているアルミニウ ム招よびアルミニウム合金の脱脂，洗浄作業に使用され る有機ハロゲン化物（たと觉ば四塩化炭素，トリクロエ チレンなど）がしばしばアルミニウム面を腐食したり， ときには爆発的に反応することが報じられている。著者 はこれらの事実に注目し，この反応を基礎的に解明する とともに前述作業の安全管理に資することを目的として この研究を行なった。アルミニウムと有機ハロゲン化物 との反応に执いては，まず反応系に八ロゲン化アルミニ ウムを生成し，これが触媒として働いて反応自体を加速 的に促進し, 誘導期を経てのちアルミニウム溶解反応が 急速に進行する現象がみられる。既往の研究は爆発の原 因となる反応機構の基礎研究としては十分でなく，また 防災化学的立場からも論議されていない。

本報では，まずアルミニウムと有機ハロゲン化物との

†有機ハロゲン化物に対するアルミニウムの挙動に関 する研究（第 1 報）

* 新鼬大学工学部(新潟県長岡市学校町)

Niigata Univ., Faculty of Eng.
反応に関する既往の研究についての調査結果を述へ，そ れを基として誘導期测定方法を検討し，また誘導期存在 の原因について実験を行なった結果を報告する。な牤安 定剤添加による誘導期の延長, アルミニウム溶解機構に ついては別報にゆずる。

\section{2. 既 往の 研 究}

\section{2-1 アルミニウムと有機ハロゲン化物との反応}

アルミニウムは適当に処理して表面を活性化しないと 容易には反伈しない。そこで既往の研究としては，高温 の乾燥水素父流中でアルミニウム面の酸化皮膜を還元し て活性化させる方法1)，水銀を加えてアルミニウム表面 をアマルガム化する方法 ${ }^{2}$ がある。このとき有機ハロダ ン化物として $\mathrm{CCl}_{4}$ を用いれば次式のようにへキサクロ ルェタンがえられるが,

$$
6 \mathrm{CCl}_{4}+2 \mathrm{Al}=3 \mathrm{C}_{2} \mathrm{Cl}_{6}+2 \mathrm{AlCl}_{3}
$$

他の有機ハロゲン化物の場合も同様に 2 分子結合反応に よってそれぞれの有機化合物を得ることができる。また 反応によって副生する $\mathrm{AlCl}_{3}$ を利用するのでなく，あら かじめ $\left.\left.\mathrm{HgCl}_{2}{ }^{3}\right) ， \mathrm{AlCl}_{3}{ }^{4}\right), \mathrm{FeCl}_{3}{ }^{5}$ )を触媒として加兄て括 くう法がある。アルミニウムが未処理で触媒が無添加の 
場合には，高温で長時間保たねば容易には反応を開始し ない。6)7)含有水分の影響が大きく，とくに低温（室温） では数カ月の間反応させえない。8)

以上の1930年以前の研究結果では，いずれる反応を進 行させてへキサクロルエタンなどの有機物質を製造する ことを目的としている。また誘導期の存在に気づくもの はなかったが，1947年浅岡らは未処理の砂状アルミニウ ムと $\mathrm{CCl}_{4}$ とを触媒を加えることなく反応させると，自 己触媒反応に入るまでに一定の時間すなわち誘導期が存 在する事実を見出した。5)

最近では Stern らのアルミニウムと沸騰 $\mathrm{CCl}_{4}$ との区 応についてのかなりくわしい報文 ${ }^{9 \text { 11) }}$ がある。これに よると，やはり反応の当初に誘導期が存在することを認 めて扣り，この誘導期に対するアルミニウムの酸化皮膜， アルミニウム中の不純物すなわち合金組成としての Mn と $\mathrm{Mg}, \mathrm{CCl}_{4}$ 中に溶存する微量の酸素特よび水分の影響 を調べている。そしてこれらはいずれる誘導期延長の原 因になるとしている。また誘導期を過ぎた後のアルミニ ウムの溶解速度に対するアルミニウムの酸化皮膜, $\mathrm{CCl}_{4}$ 中の酸素, 水分, 塩化水素, アルミニウム中の $\mathrm{Mg}, \mathrm{Mn}$ の影響を調へ，さらに反応機構について考察している。 反応機構についてはこの Stern らの研究が重要である が，これは $\mathrm{CCl}_{4}$ についてだけでしかも沸滕状態の実験 であり，著者の行なったよ5な広範囲な研究ではない。

\section{2-2 アルミニウムと有機ハロゲン化物との 爆発的反応}

アルミニウム粉と $\mathrm{CCl}_{4}$ を含む圧力容器が $150^{\circ} \mathrm{C}$ に加 熱されたときはげしく爆発したとの報告があり ${ }^{12)}$ ，また 実験用のボールミル中で $\mathrm{CCl}_{4}$ にアルミニウム粉を分散 させようと試みて，生命ならびに財産を失なうような大 爆発を括こしたと報じられている(13)。さらにトリクロル エチレンとアルミニウムとの反応で爆発的進行が物こる ことについての報告がある14)。これによればアルミニウ ムクズとトリクロルェチレンを $80^{\circ} \mathrm{C}$ の恒温槽で加熱す ると約 $1 \mathrm{~h}$ で液体は隌色に着色し，8.5h で温度は急に $100^{\circ} \mathrm{C}$ に上昇して液体ははげしく沸騰する。それから約 $10 \mathrm{~min}$ で $500^{\circ} \mathrm{C}$ まで急昇し, 強大な白色の霧の幕を生じ, その幕は近くの地上まで打执ようになる。蓩の生成が緩 和して反応混合物は所々輝きはじめ温度はさらに $10 \mathrm{~min}$ で $1350^{\circ} \mathrm{C}$ まで年したという。

以上は外国文献によるものであるが，わが国に打いて もアルミニウムまたはアルミニウム合金の切削加工後の 脱脂などに多量のハロゲン化炭化水素が溶媒として使用 されており，むる工照では小爆発を拈こしたと伝えら れ，他の工場ではアルミニウム鋳物の表面が著しく腐食 したといわれている。

\section{2-3 要約および問題点}

問題を災害防止にしぼって既往の研究を整理すると次 のようになる。反応の進行を阻止するには (i) アルミニ ウムに不純物とくにマグネシウムを入れ，また酸化皮膜 をつけて拈く，(ii）有機ハロゲン化物に微量水分を含ま せるか，酸素を飽和させる，(1ii)反応温度を下げる，す なわち洗浄操作をあらかじめ実験によって決めた安全操 業温度以下に保つ，の三つをあげることができる。この らちマグネシウムは製品の価格および用途などによって 常に使えるとは限らない。また酸化皮膜も価格，用途に よってつけないことがある。つきに (ii)の条件である水 分や酸素を飽和させても，高温では完全とはいえない。 さらに(iii)の操業温度を下げることは有機ハロゲン化物 の洗浄能力を減ずるので有効な方法ではない。したがっ て既往の研究結果を応用しての安全操業は望めない。そ こで著者としては， $\mathrm{AlCl}_{3}$ 触媒の作用を減殺させ誘導期 を極端に延長させるような安定剤の添加が得策であると 考える。

\section{3. 反応誘尊期の測定方法}

\section{3一1 $\mathbf{C C l}_{4}$ およびアルミニウム試料}

$\mathrm{CCl}_{4}$ は市販試薬用 1 級品を乾燥後蒸留しその沸点, 密 度，屈折率を検して純粋なものとして使用した。またア ルミニウムは粒と板の 2 種類を使用した。すなわち粒状 は東化工研究室製 (Al $99 \%$ 以上, $\mathrm{SiO}_{2} 0.5 \%, \mathrm{Fe} 0.2$ 〜0.3\%) あるいは市販試薬用 (和光純薬) をふるいわけ して 30〜40メッシュとした。また板状は 2S 規格品の 厚サ $1.5 \mathrm{~mm}$ のものを切断して $5 \times 25 \mathrm{~mm}$ のリボン型と し A-400 番までの研摩紙でみがき, 10\% 炭酸ナトリウ 厶, $10 \%$ 塩酸, 水の順序で処理し, $100^{\circ} \mathrm{C}$ で $24 \mathrm{~h}$ 乾燥後 室温で $48 \mathrm{~h}$ 以上放置したものを試料とした。

\section{3-2 誘算期测定法の概要}

誘導期を過ぎるとアルミニウムの溶解は急速に増加す る。したがって測定法としては，アルミニウムの溶解減 量または液相中のアルミニウム濃度の急増点を求める方 法が考えられる。このうちアルミニウムの溶解減量を求 める重量法は Stern ら”) が既に行なっているが，これ らの方法は操作がかなり繁雑である。そこで著者は誘導 期を過ぎて液相中に生ずるハロゲン化アルミニウムの付 加化合物が呈する腤カッ色ないし黒色の発色をもって誘 導期終点を識刚する方法を提案し，これが上記方法と比 較して簡易迅速で，かつ精度も高いことを認めた。つぎ にその概要を要す。

3-2-1 アルミニウムの溶解減量から求める力法（重 量法)

板状アルミニウムの5ち重量が 0.49〜0.51gの範囲に あるものを選び，䜣確に棓ったその 1 枚と， $\mathrm{CCl}_{4} 30.0 \mathrm{~g}$ を反応容器（硬所ガラス製の試験管, 直径 $30 \mathrm{~mm}$, 長业 
$200 \mathrm{~mm}$, 内容約 $110 \mathrm{ml}$ ) に入れ, 還流冷却器と温度計を 付して, あらかじめ $85^{\circ}$ 亿加熱してある水浴につける。 $1 \mathrm{~min}$ 以内で沸駡を開始するので，この時刻を起点とす る。ある時間経過後内容物を取り出し, アルミニウム板 を水洗乾燥後, 精確に計って, その重量から溶解量を求 める。溶解時間を種々に変え、多数の繰返し実験を行な って, 溶解量と時間との関係曲線の屈曲点を誘導期とす る。

3-2-2 液相中のアルミニウムを分析定量する方法 (分析法)

この方法では液相の一部を一定時間毎に取りだして， その中に含まれるアルミニウム量をアルミノンを用いて 比色分析する。すなわちアルミニウム粒 $2.5 \mathrm{~g}$ と $\mathrm{CCl}_{4}$ $150 \mathrm{~g}$ の混合物を $300 \mathrm{ml}$ の三つロフラスコに入れ，これ 飞温度計および還流冷却器を付する。 $85^{\circ} \mathrm{C}$ 水浴につけ て沸騰開始を起点として一定時間毎にピペットで内容液 $5 \mathrm{ml}$ を取り出し，清浄な小ビンに眝える。このような試 料採取は液相が黒変してからも，さらに2〜3回続ける。 採取した各試料にはアルミノン, 眽酸アンモン, グリセ リンなどを加えて $\mathrm{pH}$ を7.1〜 7.3 亿保持し, 光電比色 計にかけてアルミニウム濃度を求める。そしてアルミニ ウム濃度急增の時間を誘導期とする。

3-2-3 液相の透過光量を測定する方法 (光度法)

反応液相中を通過する光の量をセレン光電池を用いて 測定する。光源として $200 \mathrm{~W}$ の白色電球を用いスリット を通して光が反応容器の液相の中央へあたるようにす る。そして通過する光量を光電池によって一定時間毎に 測定する。光電池としては写真用の露出計を代用し， ASA を 100 にあわせてL.V. (Light Value) の読みを とった。誘導期を過ぎて $\mathrm{AlCl}_{3}$ をわずかでも生ずると， 次式のように過剩の $\mathrm{CCl}_{4}$ と暗カッ色ないし黒色の付加 化合物 $\mathrm{CCl}_{3}{ }^{+}\left[\mathrm{AlCl}_{4}\right]-$ を生ずる ${ }^{15)}$ と誘過光量を減ずるの で, このL.V.急変の時間を誘導期とすることができる。

$$
\mathrm{AlCl}_{3}+\mathrm{CCl}_{4} \longrightarrow \mathrm{CCl}_{3}+\left[\mathrm{AlCl}_{4}\right]^{-}
$$

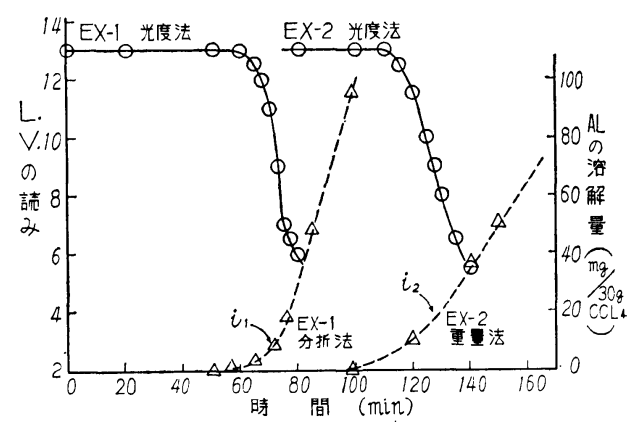

$\mathrm{EX}-1\left\{\begin{array}{l}\mathrm{A} l \text { 粒 } 2.5 \mathrm{~g}, \mathrm{CCl}_{4} 150 \mathrm{~g} \\ \text { Ind. P. } 73.5 \pm 3.5 \mathrm{~min}\end{array} \mathrm{EX}-2\left\{\begin{array}{l}\mathrm{A} l \text { 板 } 0.5 \mathrm{~g}, \mathrm{CC} l_{4} 30 \mathrm{~g} \\ \text { Ind.P. } 128.5 \pm 6.5 \mathrm{~min}\end{array}\right.\right.$

第 1 図 誘導期测定法の比輘
な怙光が誘導期扔よびアルミニウムの溶解速度に影響を 与えないことは，あらかじめ上記の重量法で確かめてあ る。反応容器は重量法で用いたと同じ試験管または分析 法で用いた三つロフラスコを使い，試薬の量および操作 方法も上記 (1) または (2) と同じにした。

\section{3-3 誘算期測定法の検討}

上記 (1)，(2)，(3) 法による測定結果の一例を第 1 図に 示した。重量法または分析法では溶解曲線の屈曲点から 比較的精確に誘導期（四中の $\mathrm{i}$ 点）を求めることができ る。光度法に扣いてもこの $\mathrm{i}$ 点付近の時間に L.V. 急変 の中心があるので, 誘導期測定が可能である。L.V.11で は暗カッ色なるも透明， 6〜 7 では黒色完全に不透明で ある。正確な誘導期は 8.5 9.5 の範囲にあると思われ るが，着色の程度としては暗カッ色不透明ということが できよう。このように光度法は重量法や分析法と同様に 比較的精確な測定を行ならことができ，しかも 1 回の測 定で誘導期を求めることができる。重量法ではアルミニ ウム板の溶解試験を時間を変えて数多く繰返し行なう必 要があり，分析法では一定時間毎に試料を取りだして分 析するという繁雑さがある。光度法はこれらに比へ簡便 有利で, アルミニウム試料として板状はもちろん, 粒状, 粉状などあらゆる形態について測定可能であることも有 利である。

実際の測定に当っては光度法をさらに簡略化すること ができる。すなわち, 光度法の急変点の時間は液相が喑 カッ色不透明になる時間と一致する。したがって単に肉 眼で観察して無色透明から急に暗カッ色不透明になる時 間を測定すればよい。ここでは $\mathrm{CCl}_{4}$ についての例を示 したが，他の種々の有機ハロゲン化物についても同様 で, やはり重量法との比較検討による肉眼による観察で 十分であることが確かめられた。よって以下に述べる本 研究の各実験においては, いずれる肉眼に上る観察法を 用いた。

\section{4. 反応誘導期の測定および考察}

\section{4一1 反応誘算期に対する考察}

Stern らは $\mathrm{Al}$ と $\mathrm{CCl}_{4}$ の反応に直流電圧をかけて影響 のないことから電気化学的には究明できないとして特 り，著者も白金極またはアルミニウム極を挿入して直流 $50 \mathrm{~V}$ まで電圧をかけてみたが，誘導期にもアルミニウム 極の溶解速度にも影響がなかった。したがって，この反 応はイオン反応ではなくラジカル反応であるとした方が 妥当性が大きい。そこで $\mathrm{CCl}_{4}$ は (A) 式の上5に解離し て遊離ラジカル・Cl を生じ，これがアルミニウムと反応 して (B) 式のよ5に $\mathrm{AlCl}_{3}$ を生ずると考兄られる。(A) 式は吸熱反応である15)16)ので,

$$
\mathrm{CCl}_{4} \longrightarrow{ }^{\cdot} \mathrm{CCl}_{3}+{ }^{\cdot} \mathrm{Cl}
$$


Vol. 13, No. 8, 1962 アルミニウムと有㙨ハロゲン化物との反忘の誘導期について

$$
\mathrm{Al}+3 \cdot \mathrm{C} \longrightarrow \mathrm{AiCl}_{3}
$$

反応の進行には加熱して・Cl の生成を促進させる必要が ある。また一般にラジカル反応に対して，水分，酸素な どが阻害作用を示すとされているが，この反応に括いて も有機ハロゲン化物に微量溶けている水分打よび酸素が ハロゲンラジカルの作用を封鎖し，(B) 式への移行を妨 げると考えられ， $\mathrm{CCl}_{4}$ について はStern らが実験的に 証明している。つぎに，普通にはアルミニウム表面に酸 化皮膜が存在するので, (B) 式に拉いても $\mathrm{AlCl}_{3}$ 生成 に対する障害があると䍐われる。

以上は既往の沸騰 $\mathrm{CCl}_{4}$ の研究を基礎として考察した ものである。

\section{4一2 $\mathrm{CCl}_{4}$ と Al の反応の誘導期に及ほす諸因子}

実験装置はこの項日の(1)，(2)，(5)では 3-2（重量法） で述べたと同じ硬質ガラス製試験管を使用した。(3)，(4) の装置はその実験項目のところで説明する。

4-2-1 酸素, 水分添加执よびアルミニウムの酸化皮 膜

これらについては, Stern らの研究があるが，いずれ も $\mathrm{CCl}_{4}$ の沸騰状態に特けるものである。著者は沸騰状 態括よび沸点以下に打影響についても実験した。し かしどちらかといえばStern らの追試であるので，実験 の詳細は略し結果の要約だけを以下に述べる。（i）沸点 よりわずかでも低いと，これらの因子つうち水分と酸化 皮膜の影響が大さく誘導期をほとんど無限時間に近づけ る,（ii）沸騰状態では誘導期を数倍に延ばすだけで，そ の影響は大さくない。すなわち $\mathrm{CCl}_{4}$ を沸騰することに よりこれらの影響を比較的速やかに除去できる。（iii） 酸素についてはStern ら㹥誘導期を 2 倍に延ばすことを 示しているが，著者の実験では誘導期を大きく延ばすよ うな固有な原因ではない。

第1表 ハロゲン颃よび塩化水䒺添加の影響

\begin{tabular}{|c|c|c|c|c|}
\hline \multirow{2}{*}{$\begin{array}{l}\text { ハロゲンま } \\
\text { たはハロゲ } \\
\text { ン化水素 }\end{array}$} & \multirow{2}{*}{$\begin{array}{c}\text { 添 加 量 } \\
\mathrm{g}\end{array}$} & \multirow{2}{*}{$\begin{array}{c}\text { 誘 導 期 } \\
\min \end{array}$} & \multicolumn{2}{|c|}{ 解離エネルギー } \\
\hline & & & $\mathrm{kcal} / \mathrm{mol}$ & 文献 \\
\hline $\mathrm{I}-\mathrm{I}$ & $0.01 \sim 0.5$ & 1 以下 & $\begin{array}{l}35.1 \\
35.514 \\
35.547 \\
31.6\end{array}$ & $\begin{array}{l}20) \\
21) \\
22) \\
23)\end{array}$ \\
\hline $\mathrm{Br}-\mathrm{Br}$ & 0.1 & 1 以下 & $\begin{array}{l}46.5 \\
41.2\end{array}$ & $\begin{array}{l}\text { 24) } \\
23 \text { ) }\end{array}$ \\
\hline $\mathrm{Cl}-\mathrm{Cl}$ & 飽 和 & 2 以下 & 54 & 18) \\
\hline $\mathrm{H}-\mathrm{Br}$ & - & 一 & 85.8 & 19) \\
\hline $\mathrm{H}-\mathrm{Cl}$ & 飽 和 & 73 & $>85.8$ & - \\
\hline $\mathrm{CCl}_{3}-\mathrm{Cl}$ & 一 & 73 & $\begin{array}{r}65 \\
\geqq 70\end{array}$ & $\begin{array}{l}16) \\
15)\end{array}$ \\
\hline
\end{tabular}

$\mathrm{Al}$ 粒 $0.5 \mathrm{~g}, \mathrm{CCl}_{4} 30.0 \mathrm{~g}$, 反応温度: 沸点

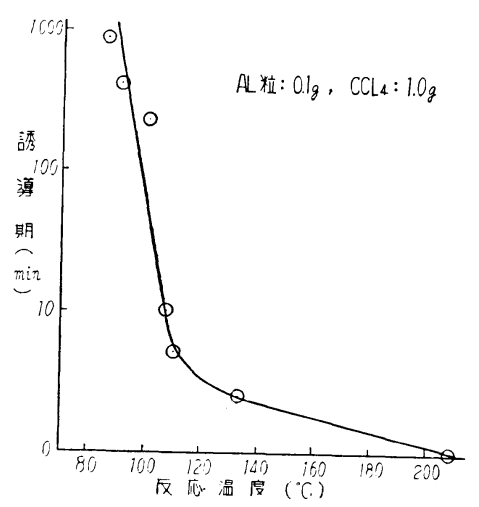

第 2 図封管中の反応

4-2-2 ハロダン打よび塩化水素添加

前記 (A) 式が反応の律速過程になるものとすれば， 、 ロゲンラジカルを生じやすい試薬を微量添加しても誘導 期は短縮するはずである。ここではハロゲン $\mathrm{X}_{2}$ から・X ラジカルを遊離する解離エネルギーが小さいことは利用 して, $\mathrm{CCl}_{4}$ にこれらを添加して誘導期を測定してみ た。その結果は第 1 表に示したが, 塩素, 真素, ヨウ素 はいずれる誘導期を注とんど零にする。そして比較的低 温（50ㄷ以上）に持いても反応しやすく，水分や酸化皮 膜の影響はほとんど考虑する必要がない。

また塩化水素の添加では，その解離エネルギーが(A) 式より大であるので, 誘導期の短縮には有効でないこと が確かめられた。

4-2-3 封管中での高温反応

$\mathrm{CCl}_{4}$ とアルミニウム試料を反応容器中に封じ込めば, 浴温を高くして沸点以上での反応も可能である。反応容 器としては径 $15 \mathrm{~mm}$ の試験管を用い, これにアルミニウ 么粒 $0.1 \mathrm{~g}$ と $\mathrm{CCl}_{1} 1.0 \mathrm{~g}$ を入れて内容を約 $20 \mathrm{ml}$ になる ように溶封してしまう（試料を少なくするのは誘導期を 過ぎてから爆発する恐れがあるからである)。85,90ㄷ の 反応ではこの溶封試験管をそれぞれの温度の恒温槽中に $100^{\circ} \mathrm{C}$ の反応では沸騰水につけて誘導期を測定した。ま た $100^{\circ} \mathrm{C}$ 以上の実験では，イソブチルアルコール，シク ロヘキサノール, キシロールまたはニトロベンゼンの沸 騰蒸気中につりさげて反応させたが，それぞれの反応温 度は $107,110,133,205^{\circ} \mathrm{C}$ であった。

温度が高いほど (i) ·Cl ラジカル生成が促進される， (ii) アルミニウム面上の吸着水分の離脱が速やかに拉こ る, の理由により誘導期はかなり短縮することが期待さ れる。その実験結果は第 2 図に示したが，観察上の現象 としては, $107^{\circ} \mathrm{C}$ 上では初め液相の沸騰現象が見られ， この間に $\mathrm{CCl}_{4}$ の気化現象とアルミニウム面の吸着水分 の離脱が括こると考えられる。そして $100^{\circ} \mathrm{C}$ 以下の反応 では内容液相は最初より静止状態であって, 長時間のあ 


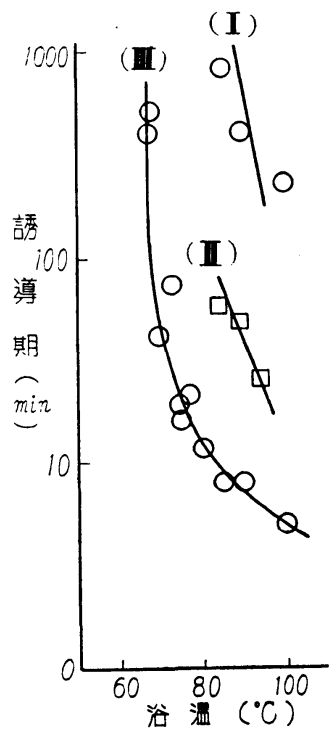

$\mathrm{A} l$ 粒: $0.1 \mathrm{~g}, \quad \mathrm{CCl}_{4} 1.0 \mathrm{~g}$

(I) : 静止

(II) : $260 \mathrm{rpm}$ (回転)

(III): 100 回/ $\mathrm{min}$ (フリマゼ)

第3図カキマゼの影響

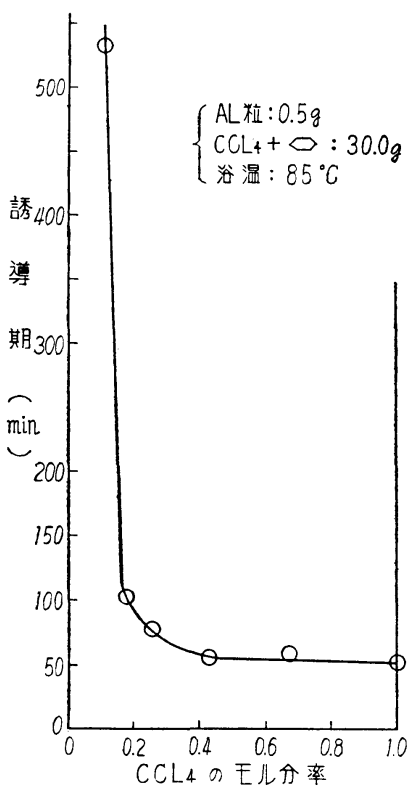

第 4 図 $\mathrm{CCl}_{4}$ とベンゼンの混 合溶液の誘導期

キマゼ棒にしばりつける。カキマゼ棒は 260 $\mathrm{rpm}$ とし, 温度は $85,90,95^{\circ} \mathrm{C}$ に变之て誘 導期を測定した。この場合，反応物質は密閉 器中にあるので, $\mathrm{CCl}_{4}$ の気化は 1 部だけにと どまり，アルミニウム粒は液相中にある。そ の実駼結果は第 3 図の (II) で示したが，比較 のため静止状態の結果を( I )で示した。また カキマゼ効果をさらによくするめフリマゼ機 を使って溶封試験管を約 100 回/ $\mathrm{min}$ の速度 で上下に運動させた。そして，この場合には 60〜100号に変えて誘導期を測定し，その結 果は第3図の(III)で示した。カキマゼを特こ な5 と誘導期は静止状態にくらべ，かなり短 縮し，沸点以下に执いてる反応させ 3 る。

上の実験拈よび前項の実験の結果，（i）誘 導期存在の原因としてアルミニウム面に吸着 した水分は大きく考慮する必要がある。（ii） この水分除去には $\mathrm{CCl}_{4}$ の沸騰によるカキマ ゼを行なってもよいが，機械的にかきまぜて もよいことがわかった。

\section{4-2-5 $\mathrm{CCl}_{4}$ のベンゼンによる希釈}

$\mathrm{CCl}_{4}$ がアルミニウムの酸化皮膜層を拡散し, 内部の純

いだ変化が見られない。

この $100^{\circ} \mathrm{C}$ 以下の場合は反応がかなり遅引し，これは 封管中では 85〜 $100^{\circ} \mathrm{C}$ でも沸騰がおこらず，このよ5な 静止状態ではいったんアルミニウム面に吸着した水分は 離脱がきわめて困難となるからと考えられる。これに反 し $107^{\circ} \mathrm{C}$ 以上では温度が高いほど誘導期は短縮し，これ は温度が高い汪ど上記の（i）（ii）の原因が作起して反 㐫が促進されるからと考えられる。この実験によっても 沸騰するか否かで誘導期の脣短に大きな差を生ずること. がわかった。

4-2-4 カキマゼ

既述のように沸点よりわずかに低い温度では誘導期は 極端に延びる。したがって「沸滕する」ということが誘 導期短樎の絶対的因子のよ5に思え，沸騰によって生ず る蒸気が液体よりもアルミニウムと反応しやすいのでは ないかという疑問が括こる。そこでアルミニウム板を $\mathrm{CCl}_{4}$ の沸騰蒸気中につりさげて誘導期を測定してみた が，蒸気の供給が十分多い場合でも，液中でよりわずか に誘導期は遅延する。したがって沸騰蒸気がとくに反応 しやすいということはなく，前項で述べたようにアルミ ニウム面上の吸着水分を離脱させるのに沸騰作用を利用 しているという考え方の汪うが妥当である。

そこで沸騰のかわりに強いカキマゼを行なっても誘導 期は短縮するはずであり，このことを確かめるため，以 下に述べるような実験を行なった。前項と同じく試料を 試験管に溶封し，これを恒温槽中に取りつけたガラスカ
アルミニウム層に達してから反応するものとすれば，誘 導期に対して Fick の拡散法則が適用される。拡散速度 は $\mathrm{CCl}_{4}$ の濃度傾斜に比例するから, この反応に関係の ない試薬で希釈すると誘導期が延長するはずである。希 釈㨽としては，(i) $\mathrm{CCl}_{4}$ とよく溶けあ ここと，(ii）沸点 が $\mathrm{CCl}_{4}$ の沸点に近いこと, (iii) 微量添加により誘導期 を延長させたり，短縮したりする性質のないこと，(iv） アルミニウム面に吸着したり $\mathrm{AlCl}_{3}$ と反応したりする性 貎のないこと，などの条件をそなえる必要がある。ここ ではベンゼンを適当な希釈剂として第4図の実験結果を えた。これによると $\mathrm{CCl}_{4}$ の $\mathrm{mol}$ 分率を0.2くらいまで 希釈しても $\mathrm{CCl}_{4}$ のみの場合とほとんど変わらない。し たがって，拡散速度が反応の律速過程ではない。

\section{4-3 種々の有機ハロゲン化物とアルミニウムの反応 の誘幕期}

種々の有機ハロゲン化物からハロゲンラジカルを遊離 する解離エネルギーは文献によると，その種類により 40 〜 $90 \mathrm{kcal} / \mathrm{mol}$ といらかなり広い範囲にわかれている。 既述の (A)式が反応の律速過程になるとすれば，この反 応熱に相当する解離エネルギーの大小が誘導期の長短に 影響するはずである。このことを確かめるため, トリク ロルェチレン，テトラクロルェタンなど 20 種類の有機ハ ロゲン化物について誘導期を测定した。すなわちアルミ ニウム粒 $0.5 \mathrm{~g}$ と有機ハロゲン化物 $30 \mathrm{~g}$ を反応させて誘 導期を測定し，浴温を種々に变えて，ある温度以下では 
第2表 アルミニウムと有機ハロゲン化 物の反応の臨界温度（その1）

\begin{tabular}{|c|c|c|c|}
\hline 有機ハロゲン化物 & 分子 式 & $\begin{array}{l}\text { 沸点 } \\
{ }^{\circ} \mathrm{C}\end{array}$ & 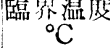 \\
\hline 四塩 化 炭 素 & $\mathrm{CCl}_{4}$ & 76.7 & 76.7 \\
\hline クロロホルム & $\mathrm{CHCl}_{3}$ & 61 & 61 \\
\hline クロルブロムメタン & $\mathrm{CH}_{2} \mathrm{ClBr}$ & 69 & 69 \\
\hline シクロルエタン & $\mathrm{CH}_{2} \mathrm{Cl} \cdot \mathrm{CH}_{2} \mathrm{Cl}$ & 83.5 & 83.5 \\
\hline 莫 化 エチ ル & $\mathrm{C}_{2} \mathrm{H}_{5} \mathrm{Br}$ & 39 & 39 \\
\hline 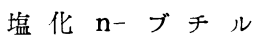 & $\mathrm{n}-\mathrm{C}_{4} \mathrm{H}_{9} \mathrm{Cl}$ & 78 & 78 \\
\hline 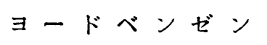 & $\mathrm{C}_{6} \mathrm{H}_{5} \mathrm{I}$ & 189 & 189 \\
\hline $\left.\begin{array}{l}\text { ヘキサクロルエタン } \\
\text { ベンゼン溶 液 }\end{array}\right\}$ & $\begin{array}{c}\mathrm{CCl}_{3} \cdot \mathrm{CCl}_{3} \\
1: 1.78 \text { モル比 }\end{array}$ & 96 & 96 \\
\hline
\end{tabular}

アルミニウム粒 $0.5 \mathrm{~g}$, 有機ハロゲン化物 $30.0 \mathrm{~g}$

誘導期が䑯限時間に近づくと 5 臨界温度も测定した。 この臨界温度測定によれば，必ずしも沸騰状態でなくと も，かなりの低温で反応するものもあって，ブロモホル ムなどではとの融点が臨界温度となる。またジクロルエ チレンのよ5に, あらかじめアルミニウムの酸化皮膜を 削り，はげしい沸騰状態に括いても2000 min 以上反応 しないものもある。実験結果のうち臨界温度が沸点と合 致するものを第 2 表に, 反応が容易で臨界温度が沸点以 下であるものを第 3 表に, 反応の進行が困難で臨界温度 を求めえなかったものを第 4 表に示した。

有機物質の解離エネルギーについては Szwarc ${ }^{17)}$ の総 説がある。そのなかからハロゲン化物についてのものを 要約すると次のようになる。（i）ハロゲンの種類につい ては $\mathrm{Cl}>\mathrm{Br}>\mathrm{I}$ の順に解離エネルギー小, (ii) ベンゼ ソ核および 2 重結合の炭素についた八ログンは解離エネ ルギーが他のものにくらべ大，(iii）アルキル基の炭素数 が多い注ど解離エネルギーは小，(iv)ベンジル基につい たハロゲンの解離エネルギーはきわめて小，（v）多八ロ ゲン化物の八ロゲン数が多い注ど解離エネルギーは小, (vi)ナフタリン核についだロゲンはベンゼン核のそれ よりも解離ェネルギーは小，である。これらの解離ェネ ルギーの大小と第 2〜 4 表に示したアルミニウムとの反 応のしやすさの順位が比較的よく一致しており，ハロゲ ソラジカル生成の困難さが誘導期存在の原因の主なもの であることは疑いない。

な拉，第 3 表のうちブロモホルム， ヨードホルム, 塩 化ベンジル，テトラクロルェタンなどは臨界温度よりわ ずかに高温にすると，その沸点以下で誘導期は零とな る。すなわちハロゲンラジカルが生じやすく，その濃度 がある值以上になれば直接アルミニウムの酸化皮膜に作 用すると考えてよい。

\section{5. 結 論}

1）アルミニウムと有機ハロゲン化物との反応に関す
第3表 アルミニウムと有機ハロゲン化 物の反応の臨界温度 (その 2 )

\begin{tabular}{|c|c|c|c|c|}
\hline 住機ハロゲン化物 & 分子式 & $\mid$ 沸点 & 智界温 & 備 \\
\hline ブロモホルム & $\mathrm{CHBr}_{3}$ & 150 & 8 & m.p. $8^{\circ} \mathrm{C}$ \\
\hline$\Xi$ ードホルム & $\mathrm{CHI}_{3}$ & 昇華 & 119 & " $119^{\circ} \mathrm{C}$ \\
\hline テトラクロルエタン & $\mathrm{CHCl}_{2} \cdot \mathrm{CHCl}_{2}$ & 146 & 102 & \\
\hline ペンタクロルエタン & $\mathrm{CHCl}_{2} \cdot \mathrm{CCl}_{3}$ & 159 & 102 & \\
\hline ヨウ 化 エチ ル & $\mathrm{C}_{2} \mathrm{H}_{5} \mathrm{I}$ & 72 & 69.5 & \\
\hline 塩化 $\mathrm{n}$-ステアリル & $\mathrm{n}-\mathrm{C}_{18} \mathrm{H}_{37} \mathrm{Cl}$ & 220 & 210 & \\
\hline 罝 化ベンジル & $\mathrm{C}_{6} \mathrm{H}_{5} \mathrm{CH}_{2} \mathrm{Cl}$ & 179 & 82 & \\
\hline$\alpha$-ブロムナフタリン & $\mathrm{C}_{10} \mathrm{H}_{7} \mathrm{Br}$ & 281 & 222 & \\
\hline
\end{tabular}

アルミニウム粒 $0.5 \mathrm{~g}$, 有機ハロゲン化物 $30.0 \mathrm{~g}$

第 4 表 アルミニウムと有機ハロゲン化 物の反応の臨界温度（その 3 ）

\begin{tabular}{|c|c|c|c|c|}
\hline 有機ハロゲン化物 & 分子式 & 沸点 & 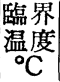 & 備 \\
\hline トリクロルエチレン & $\mathrm{CHCl}=\mathrm{CCl}_{2}$ & 87 & - & $\begin{array}{l}\mathrm{AlCl}_{3} \text { を加党 } \\
\text { ると反応する }\end{array}$ \\
\hline ジクルエチレン & $\mathrm{CHCl}=\mathrm{CHCl}$ & 60 & - & "I \\
\hline クロルベンゼン & $\mathrm{C}_{6} \mathrm{H}_{5} \mathrm{Cl}$ & 132 & - & $\begin{array}{l}\mathrm{AlCl}_{3} \text { を加え } \\
\text { ても反応しな } \\
\text { ． }\end{array}$ \\
\hline ブロムベンゼン & $\mathrm{C}_{6} \mathrm{H}_{5} \mathrm{Br}$ & 156 & 一 & 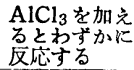 \\
\hline
\end{tabular}

アルミニウム粒 $0.5 \mathrm{~g}$, 有機ハロゲン化物 $30.0 \mathrm{~g}$

る既往の研究を調査し, 防災化学的解決の問題点を明ら かにした。とくに誘導期の存在に着目し，これを延長さ せて爆発的反応を阻止するような安定剤の発見が得策で あるとした。

2）誘導期測定法を検討し，著者の提案した簡易法が 迅速から精度も高いことを明らかにした。

3）誘導期を支配する要因を明らかにするため種々の 実験を試みたが，その結論を要約して示すと次のように なる。誘導期存在の律速過程は (A)'式であり,

$$
\begin{aligned}
& \mathrm{RX} \longrightarrow \cdot \mathrm{R}+{ }^{\circ} \mathrm{X} \quad(\mathrm{A})^{\prime} \\
& \mathrm{Al}+3 \cdot \mathrm{X} \longrightarrow \mathrm{AlX}_{3}(\mathrm{~B})^{\prime}
\end{aligned}
$$

この式の解離エネルギーの大小によって反応進行の容易 さ，すなわち誘導期に長短があらわれる。有機ハロゲン 化物の種類により，（i）解離エネルギーの小なるもので は誘導期は短かく, 微量水分やアルミニウムの酸化皮膜 は反応阻害の原因とはならない，(ii）解離エネルギーの 中程度のものでは· $\mathrm{X}$ 生成の過程, すなわち(A)'式に対 して水分および酸化皮膜が阻害作用を呈し，沸騰あるい はカキマゼによってこれらの阻害の原因を排除できる， (iii)解離エネルギーの大なるものでは誘導期が極端に長 く, 水分や酸化皮膜の影響も大さい。

誘導期を過ぎると急速に反応が進行するので, 爆発防 止のためには $(\mathrm{A})^{\prime}$ 式の進行，すなわちハロゲンラジカ 
ルの生成を防ぎ誘導期を杫端に延長させで括くべきです る。

この研究は著者が富山大学工学部浅岡研究空在勤中に 行なったものである。種 々ご指導下さった浅岡忠知教授 に感謝する。また本研究に対し熱心な討論および助言を いただいた東京工大教授向 正夫先生に深く感刻する。

(本研究の一部は昭和36年 4 月, 日本化学会第14年会 で発表した）

\section{文献}

(1) A.C. Ray, S. Dutt, J. Ind. Chem. Soc., 5, 103 (1928)

(2) K. A. Hoffmann, E.Seiler, Ber., 38, 3058 (1905)

（3）有馬, 日本特竍, 72943 (昭 2)

(4) G. M. Bartlett, A.P., 800371 (1931)

（5）浅岡, 中原, 湆川, 森, 日本化学会年会 (昭22)

(6) E. V. Zappi, Anales Soc. Quim. Arzentina, 2, 217 (1914); C. A., 9, 3001 (1915)

(7) S. G. Sastry, J. Soc. Chem. Ind. (London), 35, 94 (1916)

(8) F. H. Rhodes, J. T. Carty, Ind. Eng. Chem., 17, 909 (1925)

(9) M. Stern, H. H. Uhlig, J. Electrochem. Soc., 99, 381 (1952)

(10) M. Stern, H. H. Uhlig, J. Electrochem. Soc., 99, 389 (1952)
(11) M. Stern, H. H. Uhlig, J. Electrochem. Soc., 100, 543 (1953)

(12) Anon., Underwriters Labs. Bull. Research, No. 34, 5 (1949)

(13) Anon., Chem. Age (London), 63, 6 (1950)

(14) L. Metz, A.Rödig, Chem. Ind. Tech., 21, 191 (1949)

(15) Miller, Willard (unpublished result); $M$. Szwarc, Chem. Rev., 47, 165 (1950)

(16) C. H. Wallace, J.E. Willard; J. Am. Chem. Soc., 72, 5275 (1950)

(17) M. Szwarc, Chem. Rev., 47, 165 (1950)

(18) F. A. Henglein, Z. Anorg. Chem., 123, 137 (1922); 142, 337 (1925)

(19) G. B. Kistiakowsky, E. R. VanArtsdalen, J. Chem., Phys., 12, 469 (1944)

(20) H. Braune, H. Ramstetter, Z. Physik. Chem., 102, 480 (1922)

(21) M. L. Perlman, G. K. Rollefson, J. Chem. Phys., 9, 362 (1914)

(22) W. G. Brown, Phys. Rev., 38, 1187 (1931)

(23) T. DeVries, W. H. Rodebush, J. Am. Chem. Soc., 49, 656 (1927)

(24) M. Bodenstein, P. Cramer, Z. Electrochem. 22, 327 (1916)

\section{「金属表面技術」 13 巻 9 号 目 次（予告）}

総 説

電気防食の実際 福 谷 英 二

研究

アルミニウム粒と四塩化炭素との反応のエーテル類，エステル類，

ニトリル類, アミン類, アミド類添加による阻害作用………………………安 川 ミ 郎

ガス浸炭窒化処理鋼の耐食性について………………………………..滝 島 延 雄

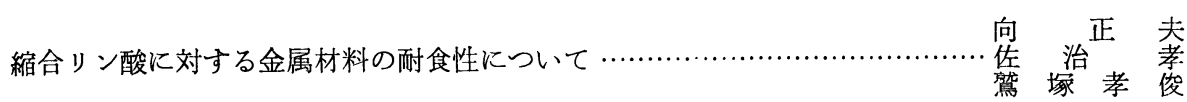

吸光光度法によるシアン化銅メッキ液中の銅の迅速速定

長 谷川和男

その他 